Joyful Learning Journal

\title{
PENGEMBANGAN MEDIA ULAR TANGGA BERBANTUAN FLASHCARD TERHADAP KETERAMPILAN MENULIS DESKRIPSI KELAS IV
}

\section{Tiarawati ${ }^{\bowtie}$, Sukardi}

Jurusan Pendidikan Guru Sekolah Dasar, Fakultas Ilmu Pendidikan, Universitas Negeri Semarang, Indonesia

\begin{abstract}
Info Artikel
Abstrak

Sejarah Artikel:

Diterima Januari 2020

Disetujui Februari

2020

Dipublikasikan Maret

2020

Keywords:

flashcard, writing

indonesian descriptions,

snake and ladder

Penelitian ini dilatarbelakangi oleh keterampilan menulis siswa rendah dan tidak adanya media pembelajaran yang bersifat praktik langsung. Jenis penelitian ini adalah penelitian pengembangan. Penelitian ini bertujuan untuk mengembangkan, menguji kelayakan, dan menguji keefektifan media ular tangga berbantuan flashcard pada materi menulis deskripsi. Subjek penelitian ini adalah siswa kelas IV SDN Mangkang Kulon 02 dengan jumlah sampel sebanyak 34 siswa. Teknik pengumpulan data menggunakan observasi, wawancara, angket, tes, dan dokumentasi. Teknik analisis data menggunakan uji normalitas, uji$\mathrm{t}$, dan n-gain. Hasil penelitian menunjukkan media ular tangga berbantuan flashcard dapat digunakan dalam pembelajaran berdasarkan persentase ahli media dan ahli materi berturut-turut sebesar $94 \%$ dan $97 \%$, dengan kategori sangat layak. Pada ujicoba pemakaian produk, hasil perhitungan uji t memperoleh $\mathrm{t}_{\text {hitung }}>\mathrm{t}_{\text {tabel }}$ yaitu 10,23>2,011. Sedangkan hasil perhitungan uji $\mathrm{n}$-gain memperoleh nilai gain sebesar 0,562 , dengan kriteria sedang. Simpulan penelitian ini adalah media ular tangga berbantuan flashcard layak dan efektif untuk digunakan dalam meningkatkan keterampilan menulis deskripsi siswa kelas IV.

\section{Abstract}

This study was motivated by the low writing learning outcames and the absence of direct practice learning media. This research is a type of research and development. This research aimed to develop, to test feasibility, and to test the effectiveness of snake and ladder media assisted on flashcard on the writes descriptions material. The subject of this research is the four grade students of SDN Mangkang Kulon 02 with a total of 34 students. The data collection techniques use observation, interviews, questionnaires, tests, and documentations. The processed data using lilliefors test, $t$ test, and gain test. The results showed that snake and ladder media assisted on flashcard could be used in learning based on the percentage of media and material experts is $94 \%$ and $97 \%$ with a very decent category. In the use of product tests shows the results of the calculation of the $t$ test obtained $t_{\text {count }}>t_{\text {table }}$ is $10.23>2.011$. While the results of the $n$-gain test calculation 0.562 with medium criteria. The conclusion of this research is that snake and ladder media assisted on flashcard is feasible to use and is effective in improving the skills of writing indonesian descriptions in four grade.
\end{abstract}

(C) 2020 Universitas Negeri Semarang

\footnotetext{
Alamat korespondensi:

Desa Pangkah RT 07/RW 04 No. 452, Kec. Karangdadap,

Kab. Pekalongan
}

E-mail: tiarawatismapat714@gmail.com

ISSN 2252-6366 


\section{PENDAHULUAN}

Berdasarkan Undang-Undang Nomor 20 Tahun 2003 tentang Sistem Pendidikan Nasional Bab III Pasal 4 Ayat (5) pendidikan diselenggarakan dengan mengembangkan budaya membaca, menulis, serta berhitung bagi segenap warga masyarakat. Menurut Peraturan Menteri Pendidikan dan Kebudayaan Nomor 21 Tahun 2016 tentang Standar Isi untuk Satuan Pendidikan Dasar dan Menengah, tingkat kompetensi yang harus dicapai pada jenjang sekolah dasar (SD) terdiri atas delapan muatan pelajaran, satu diantaranya yaitu bahasa Indonesia. Susanto (2013: 242) menjelaskan bahwa pembelajaran bahasa Indonesia di sekolah dasar erat kaitannya dengan aspek-aspek keterampilan berbahasa. Keterampilan tersebut meliputi: keterampilan mendengarkan, berbicara, membaca, dan menulis. Menulis merupakan aspek yang paling rumit atau kompleks karena penulis harus mampu menyusun, mengelola isi dari tulisan, dan dapat menyalurkannya kedalam bahasa tulis (Dalman, 2016: 2). Menurut Tarigan (2013: 4) keterampilan menulis pada seseorang tidak dapat muncul dengan sendirinya, tetapi harus dengan memperbanyak praktik dan latihan secara teratur. Latihan dan praktik tersebut dapat diwujudkan melalui proses pembelajaran dengan bantuan media pembelajaran yang sesuai dengan kebutuhan dan karakteristik siswa.

Berdasarkan data yang diperoleh melalui observasi, wawancara, dan hasil belajar pada kelas IV SDN Mangkang Kulon 02, peneliti menemukan beberapa permasalahan, diantaranya: media pembelajaran yang digunakan masih sederhana dan tidak bersifat praktik langsung sehingga membuat siswa cenderung pasif saat mengikuti pembelajaran, serta keterampilan menulis siswa juga rendah. Menurut Moch. Chabib (2017: 912) seorang guru harus pandai melakukan adaptasi model dan metode yang digunakan pada pembelajaran. Satu diantaranya adalah dengan menggunakan pendekatan bermain sambil belajar yakni dengan melibatkan keaktifan siswa dalam pembelajaran, misalnya melalui media permainan.

Karakteristik anak usia sekolah dasar masih berada dalam tahan senang bermain, sehingga media permainan dapat dijadikan sebagai alternatif media pembelajaran di kelas. Hal ini diperkuat oleh pendapat Raisatun Nisak (2012: 11) yang menyatakan bahwa permaianan dapat dijadikan sebagai sarana untuk menyalurkan pengetahuan kepada siswa karena permainan memiliki arti mendidik walaupun tidak disadari oleh orang yang melakukannya. Selain itu, kegiatan permainan dapat digunakan sebagai sarana siswa dalam bersosialisasi karena sangat memungkinkan siswa untuk bertemu dengan teman sebayanya (I Kadek Hadi Suananda, 2018: 78). Menurut Sadiman (2012: 78) permainan merupakan kegiatan yang menyenangkan dan menghibur untuk dilakukan, serta dapat memungkinkan munculnya partisipasi aktif dari siswa dalam mengikuti pembelajaran. Permainan dapat dijadikan sebagai penghilang atau pengalih rasa bosan, jenuh atau bahkan stres. Melalui permainan, otak akan lebih rileks dan perasaan akan menjadi lebih tenang, santai, dan senang (Taufik Hidayat, 2019: 59). Contoh dari media permainan adalah media ular tangga yang dimodifikasi dengan menggunakan bantuan media flashcard (kartu).

Menurut Hendrik Mentara (2017: 60) ular tangga merupakan permainan papan yang dimainkan menggunakan bidak dan dadu, serta dilakukan oleh dua orang atau lebih. Papan permainan ular tangga berisikan kotak-kotak berukuran kecil yang didalamnya terdapat gambar ular dan tangga (Nurul Musa'adah, 2017: 4). Ukuran dari papan permainan ini bergantung pada keinginan pembuat atau tidak ada aturan yang mendasar untuk ukurannya. Alat-alat yang digunakan pada permainan ini, meliputi: dadu, bidak, dan papan ular tangga (Husna, 2009: 145). Sedangkan menurut Arsyad (2014: 115) flashcard merupakan sebuah kartu yang mengarahkan atau mengingatkan siswa mengenai hal-hal yang berkaitan dengan simbol, teks, atau gambar yang terdapat pada kartu tersebut. Penggunaan flashcard memudahkan siswa memahami materi yang diajarkan dan membuat siswa tidak mudah merasa bosan karena kegiatan pembelajaran yang dilakukan tidak sekedar mendengarkan penjelasan atau ceramah dari guru saja, tetapi melibatkan kegiatan lain juga seperti mengamati atau mendemonstrasikan apa yang dilihat dari gambar yang terdapat pada media flashcard tersebut (Indot, 2018: 667-668). Maka, melalui media ular tangga berbantuan flashcard diharapkan dapat meningkatkan aktivitas atau partisipasi aktif siswa dan meningkatkan keterampilan menulis siswa melalui informasi yang terdapat pada kartu yang ia peroleh.

Pernyataan diatas sesuai dengan penelitian terdahulu yang dilakukan oleh penelitian Desi Eka Pratiwi, dkk. tahun 2016 yang berjudul "Pengembangan Media Flashcard Berbasis Macromedia Flash Pada Pembelajaran Bahasa Indonesia Model Think Talk Write untuk Meningkatkan Kemampuan Menulis Siswa Kelas IV Sekolah Dasar". Hasil penelitian menunjukkan bahwa keterampilan menulis siswa dapat ditingkatkan melalui 
penggunaan flashcard. Penelitian lain yang mendukung adalah penelitian Yohana Intan Pratiwi dan Y. Haris Nusarastriya tahun 2017 yang berjudul "The Development of 'Snake and Ladder' Learning Media to Enrich Indonesian Vocabulary in Thematic Instruction for Fourth Grade Students". Penelitian ini menunjukkan bahwa produk yang dikembangkan terbukti valid untuk memperkaya kosakata bahasa Indonesia pada siswa kelas empat dalam pembelajaran tematik. Penelitian yang relevan selanjutnya adalah penelitian Herlina dan Raden Rahmi Dewi tahun 2017 yang berjudul "Flashcard Media: The Media For Developing Students Understanding for English Vocabulary at Elementary School". Penelitian ini menunjukkan bahwa pemahaman siswa tentang kosakata bahasa Inggris dapat meningkat melalui penggunaan media flashcard. Hal ini terlihat pada hasil pemahaman kosakata pada siklus I sebesar 52,5\% dan pada siklus II sebesar $80,0 \%$.

Berdasarkan uraian tersebut, maka diadakan penelitian tentang pengembangan media ular tangga berbantuan flashcard terhadap keterampilan menulis deskripsi bahasa Indonesia kelas IV. Penelitian ini bertujuan untuk mengembangkan, menguji kelayakan, dan menguji keefektifan media ular tangga berbantuan flashcard dalam meningkatkan keterampilan menulis deskripsi bahasa Indonesia pada siswa kelas IV SDN Mangkang Kulon 02 Semarang.

\section{METODE PENELITIAN}

Jenis penelitian ini adalah penelitian dan pengembangan atau yang sering dikenal dengan Research and Development (R\&D). Penelitian jenis ini merupakan metode penelitian yang bertujuan untuk mengembangkan suatu produk dan menguji keefektifannya (Sugiyono, 2015: 407). Produk yang dikembangkan dalam penelitian ini adalah media ular tangga berbantuan flashcard. Penelitian ini dilaksanakan di SDN Mangkang Kulon 02 Kota Semarang dengan subjek siswa kelas IV pada tahun ajaran 2019/2020.

$$
\text { Model pengembangan yang }
$$
digunakan dalam penelitian ini adalah model pengembangan ADDIE yang terdiri dari lima tahapan, yaitu: (1) analyze, kegiatan analisis kondisi lingkungan untuk menemukan produk yang akan dikembangkan; (2) design, kegiatan perencanaan atau perancangan produk; (3) development, kegiatan pengembangan atau perealisasian dan pengujian produk yang dikembangkan; (4) implementation, kegiatan pemakaian atau penggunaan produk; dan (5) evaluation, kegiatan penilaian kualitas produk yang dikembangkan dan langkah-langkah yang telah dilakukan.

Variabel bebas dalam penelitian ini adalah media ular tangga berbantuan flashcard. Sedangkan variabel terikatnya adalah keterampilan menulis deskripsi. Teknik pengumpulan data dalam penelitian ini menggunakan teknik tes berupa pretest dan posttest, serta teknik non tes berupa observasi, wawancara, angket, dan dokumentasi. Teknik analisis data yang digunakan dalam penelitian ini adalah analisis data produk, analisis data awal (uji normalitas), dan analisis data akhir (uji t dan uji n-gain).

\section{HASIL PENELITIAN DAN PEMBAHASAN}

Penelitian pengembangan media ular tangga berbantuan flashcard pada muatan pelajaran bahasa Indonesia materi menulis deskripsi di kelas IV SDN Mangkang Kulon 02 membahas beberapa hal, diantaranya: (1) hasil pengembangan media ular tangga berbantuan flashcard; (2) penilaian kelayakan media ular tangga berbantuan flashcard; dan (3) keefektifan media ular tangga berbantuan flashcard.

\section{Hasil Pengembangan Media Ular Tangga Berbantuan Flashcard \\ Media ular tangga berbantuan} flashcard yang dikembangkan diberi nama ARGA PENA (ular tangga petualangan nusantara) yang terdiri atas enam komponen, yaitu: papan permainan ular tangga, 34 flashcard (kartu), 1 buah dadu, 5 buah bidak, panduan penggunaan untuk guru dan siswa, serta kemasan. Media ini adalah media pembelajaran berbasis media cetak yang didesain menggunakan aplikasi Corel Draw X7 dan dicetak menggunakan kertas dan MMT sebagai bahan utamanya.

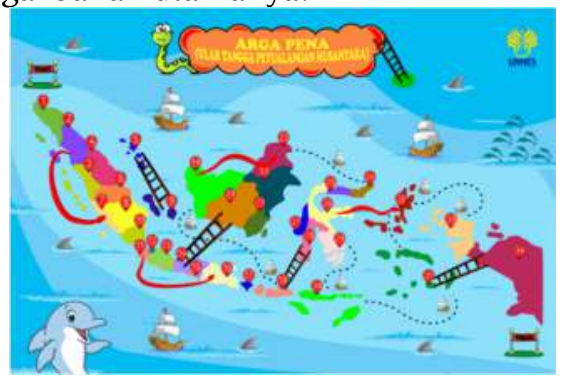

Gambar 1. Papan permainan ular tangga 


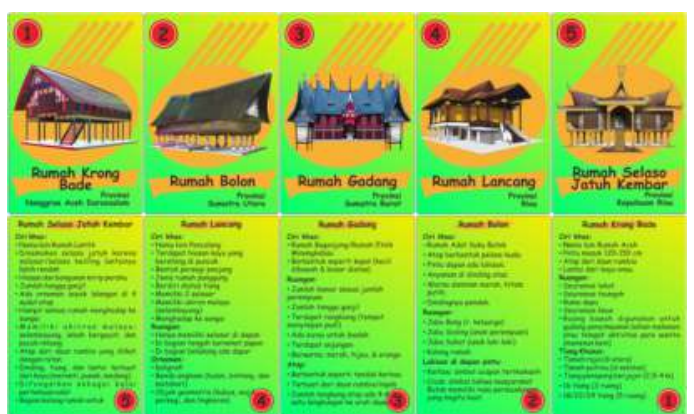

Gambar 2. Flashcard
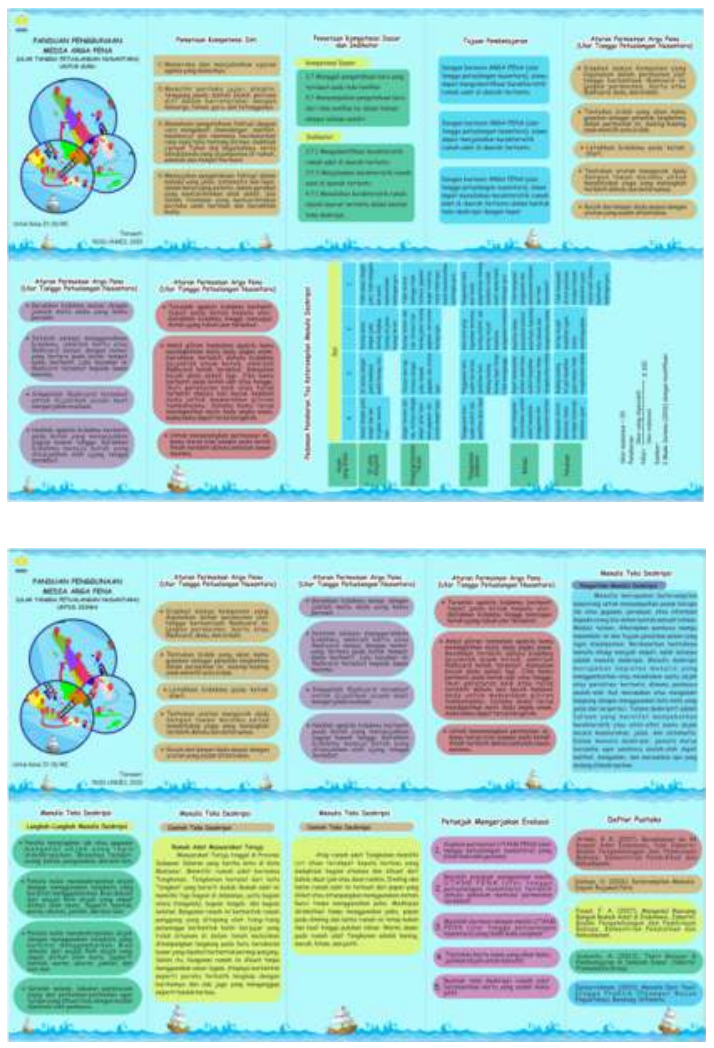

Gambar 3. Panduan penggunaan untuk guru dan siswa

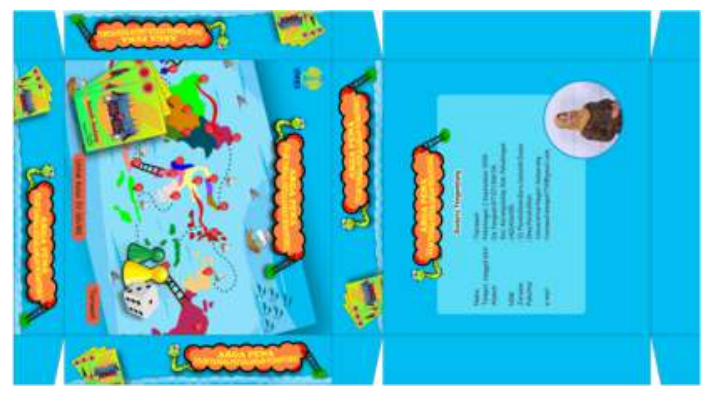

Gambar 4. Kemasan

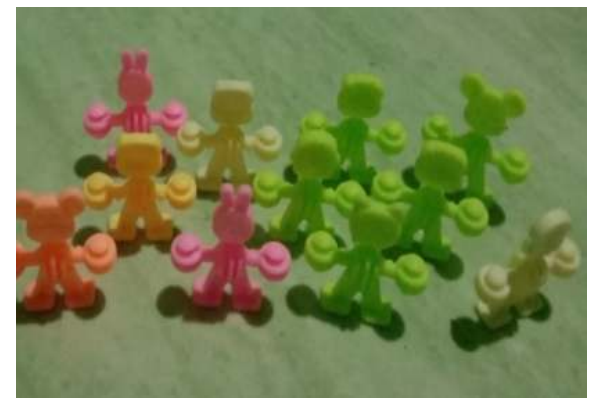

Gambar 5. Bidak

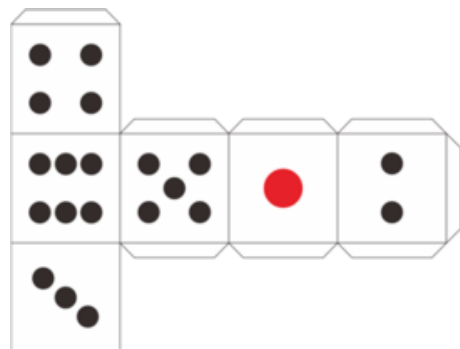

Gambar 6. Jaring-jaring dadu

\section{Penilaian Kelayakan Media Ular Tangga Berbantuan Flashcard}

Media ular tangga berbantuan flashcard yang telah selesai didesain kemudian dicetak untuk diuji kelayakannya oleh validator ahli. Penilaian kelayakan media dilakukan oleh ahli media dan ahli materi menggunakan angket penilaian validasi media. Proses penilaian kevalidan media ini bertujuan untuk menguji layak atau tidaknya media yang dikembangkan oleh peneliti diterapkan dalam kegiatan belajar mengajar di kelas. Penilaian tersebut dilakukan dengan memberikan instrumen penilaian kepada validator ahli untuk diisi. Kedua ahli memberikan penilaian sesuai dengan petunjuk yang terdapat pada instrumen serta menambahkan catatan sebagai komentar atau saran jika ada.

Instrumen penilaian validasi media berisi 13 pertanyaan yang terbagi menjadi dua aspek, yakni aspek penggunaan media dan tampilan. Penilaian dari ahli media memperoleh respon yang positif pada setiap aspeknya dengan persentase $94 \%$ dan termasuk dalam kategori sangat layak untuk diujicobakan. Sedangkan pada instrumen penilaian validasi ahli materi berisi 9 pertanyaan yang terbagi menjadi dua aspek, yakni aspek komponen penyajian dan kelayakan isi. Penilaian dari ahli materi memperoleh respon yang positif pada setiap aspeknya dengan persentase $97 \%$ dan termasuk dalam kategori sangat layak untuk diujicobakan. Berikut adalah tabel rekapitulasi hasil penilaian validasi media oleh ahli media dan ahli materi. 
Tabel 1. Rekapitulasi hasil penilaian validasi media

\begin{tabular}{ccccc}
\hline Ahli & $\begin{array}{c}\text { Skor } \\
\text { yang } \\
\text { dipero } \\
\text { leh }\end{array}$ & $\begin{array}{c}\text { Skor } \\
\text { maksi } \\
\text { mal }\end{array}$ & $\begin{array}{c}\text { Persen } \\
\text { tase }\end{array}$ & Kriteria \\
\hline Media & 49 & 52 & $94 \%$ & $\begin{array}{c}\text { Sangat } \\
\text { Layak } \\
\text { Mangat } \\
\text { Layak }\end{array}$ \\
\hline
\end{tabular}

Berdasarkan data yang diperoleh dari ahli media dan ahli materi, dapat diketahui bahwa persentase penilaian media ular tangga berbantuan flashcard termasuk dalam kategori sangat layak. Hal tersebut menunjukkan bahwa media ular tangga berbantuan flashcard sangat layak untuk diujicobakan pada pembelajaran bahasa Indonesia khususnya materi menulis deskripsi. Hasil tersebut memiliki kesamaan dengan penelitian Meriyati, dkk. tahun 2018. Penelitian ini menunjukkan bahwa media ular tangga layak untuk digunakan sebagai media pembelajaran. Hal tersebut berdasar pada penilaian dari beberapa ahli. Hasil penilaian dari ahli media memperoleh persentase sebesar $90 \%$, dari ahli materi sebesar $92 \%$, dan dari pendidik sebesar $89 \%$ dengan kriteria sangat layak.

\section{Tanggapan Siswa dan Guru}

Media ular tangga berbantuan flashcard yang telah dinyatakan layak oleh validator ahli kemudian diujicobakan pada pembelajaran bahasa Indonesia di kelas IV SDN Mangkang Kulon 02. Diakhir kegiatan pembelajaran, peneliti memberikan angket tanggapan terhadap media ular tangga berbantuan flashcard kepada siswa dan guru untuk diisi. Berikut adalah hasil rekapitulasi tanggapan siswa dan guru terhadap media ular tangga berbantuan flashcard.

Tabel 2. Hasil rekapitulasi tanggapan siswa dan guru

\begin{tabular}{ccc}
\hline Tanggapan & Persentase & Kriteria \\
\hline $\begin{array}{c}\text { Siswa (Ujicoba } \\
\text { Produk) }\end{array}$ & $\mathbf{9 7 , 5 \%}$ & $\begin{array}{c}\text { Sangat } \\
\text { Baik } \\
\text { Siswa (Ujicoba } \\
\text { Pemakaian) }\end{array}$ \\
Guru & $\mathbf{9 2 \%}$ & $\begin{array}{c}\text { Sangat } \\
\text { Baik } \\
\text { Sangat } \\
\text { Baik }\end{array}$ \\
\hline
\end{tabular}

Berdasarkan data tersebut, dapat diketahui bahwa media ular tangga berbantuan flashcard yang dikembangkan memperoleh respon yang positif dari siswa dan guru dan termasuk dalam kategori sangat baik.

\section{Keefektifan Media Ular Tangga Berbantuan Flashcard}

Keefektifan media ular tangga berbantuan flashcard dapat diketahui melalui peningkatan hasil belajar ranah keterampilan yang diperoleh siswa ketika pretest dan posttest. Hasil pretest diperoleh sebelum siswa mengikuti pembelajaran dan tidak menggunakan media ular tangga berbantuan flashcard. Sedangkan hasil posttest diperoleh setelah siswa selesai mengikuti pembelajaran menggunakan media ular tangga berbantuan flashcard. Setelah memperoleh hasil pretest dan posttest, peneliti melakukan uji normalitas untuk mengetahui hasil yang diperoleh siswa memiliki distribusi normal atau tidak. Pengujian ini dihitung menggunakan rumus uji Lilliefors berbantuan Microsoft Excel. Berikut adalah hasil perhitungan uji normalitas nilai pretest dan posttest yang diperoleh siswa.

Tabel 3. Hasil perhitungan uji normalitas nilai pretest dan posttest

\begin{tabular}{lccccc}
\hline Tindakan & L $_{\mathbf{0}}$ & L $_{\mathbf{t}}$ & $\boldsymbol{\alpha}$ & $\mathbf{n}$ & Kriteria \\
\hline Pretest & 0,143 & 0,173 & 0,05 & 25 & Normal \\
Posttest & 0,103 & 0,173 & 0,05 & 25 & Normal \\
\hline
\end{tabular}

Berdasarkan data tersebut, hasil perhitungan uji Lilliefors pada nilai pretest memperoleh hasil 0,143 . Sedangkan pada nilai posttest memperoleh hasil 0,103 . Hasil tersebut menunjukkan bahwa $\mathrm{L}_{0}$ nilai posttest dan pretest lebih kecil dari nilai kritis Lilliefors. Sehingga dapat disimpulkan bahwa data yang diperoleh memiliki distribusi normal.

Hasil uji normalitas pada nilai yang diperoleh siswa menunjukkan bahwa data tersebut berdistribusi normal. Hal ini berarti uji perbedaan rata-rata nilai pretest dan posttest dihitung menggunakan teknik statistik parametrik yakni dengan menggunakan rumus t-test. Pengujian ini bertujuan untuk mengetahui keefektifan media ular tangga berbantuan flashcard pada pembelajaran bahasa Indonesia materi menulis deskripsi. Berikut adalah hasil perhitungan uji $t$ nilai pretest dan posttest yang diperoleh siswa.

Tabel 4. Hasil perhitungan uji perbedaan ratarata nilai pretest dan posttest

\begin{tabular}{cccccc}
\hline Data & $\mathbf{t}_{\text {hitung }}$ & $\mathbf{t}_{\text {tabel }}$ & $\boldsymbol{\alpha}$ & $\mathbf{d k}$ & Kriteria \\
\cline { 1 - 3 } Pretest & 10,23 & 2,011 & 0,05 & 48 & $\begin{array}{c}\mathrm{H}_{\mathrm{a}} \\
\text { diterima }\end{array}$ \\
\hline Posttest & & &
\end{tabular}

Berdasarkan data diatas, hasil perhitungan nilai $t_{\text {hitung }}$ adalah 10,23, sedangkan nilai $t_{\text {tabel }}$ adalah 2,011 . Hal tersebut menunjukkan $t_{\text {hitung }}$ lebih besar dari $t_{\text {tabel }}(10,23$ $>$ 2,011), maka $\mathrm{H}_{\mathrm{a}}$ diterima dan $\mathrm{H}_{0}$ ditolak yang berarti media ular tangga berbantuan flashcard efektif digunakan pada pembelajaran bahasa Indonesia materi menulis deskripsi. Sehingga dapat disimpulkan bahwa media ular 
tangga berbantuan flashcard mengakibatkan perbedaan yang signifikan pada hasil belajar siswa sesudah dan sebelum menggunakan media tersebut.

Setelah menghitung perbedaan ratarata nilai pretest dan posttest, selanjutnya peneliti melakukan perhitungan peningkatan rata-rata pada nilai posttest dan pretest menggunakan analisis N-gain. Berikut adalah hasil perhitungan uji n-gain nilai pretest dan posttest yang diperoleh siswa.

Tabel 5. Hasil perhitungan uji peningkatan rata-rata pretest dan posttest

\begin{tabular}{ccccc}
\hline $\begin{array}{c}\text { Rata- } \\
\text { rata } \\
\text { pretest }\end{array}$ & $\begin{array}{c}\text { Rata- } \\
\text { rata } \\
\text { posttest }\end{array}$ & $\begin{array}{c}\text { Selisih } \\
\text { rata- } \\
\text { rata }\end{array}$ & $\begin{array}{c}\text { Nilai } \\
\text { Gain }\end{array}$ & Kriteria \\
\hline 54,8 & 80,2 & 25,4 & 0,562 & Sedang \\
\hline
\end{tabular}

Berdasarkan data diatas, dapat diketahui bahwa peningkatan rata-rata (gain) yang diperoleh adalah 0,562 dengan selisih 25,4 dan tergolong dalam kriteria sedang. Hasil tersebut membuktikan bahwa media ular tangga berbantuan flashcard efektif digunakan pada pembelajaran bahasa Indonesia materi menulis deskripsi. Dengan kata lain, media ular tangga berbantuan flashcard dapat meningkatkan hasil belajar keterampilan menulis deskripsi pada muatan pelajaran bahasa Indonesia kelas IV SDN Mangkang Kulon 02. Hal tersebut memiliki persamaan dengan penelitian Milla Nahdliya Ulwiya tahun 2018. Penelitian tersebut membuktikan bahwa media flashcard efektif digunakan untuk meningkatkan keterampilan menulis deskripsi siswa. Hal tersebut terlihat dari persentase ketuntasan hasil belajar siswa mencapai $62,5 \%$ pada siklus I dengan rata-rata nilai sebesar 81,5 , sedangkan pada siklus II mencapai $87,5 \%$ dengan rata-rata nilai sebesar 83,39.

\section{SIMPULAN}

Berdasarkan hasil penelitian dan pembahasan yang telah diuraiakan, dapat disimpulkan bahwa penelitian ini menghasilkan produk berupa media ular tangga berbantuan flashcard dengan menggunakan model pengembangan ADDIE yang terdiri atas lima tahap, yaitu: analyze, design, development, implementation, dan evaluation. Tingkat kelayakan media ular tangga berbantuan flashcard diketahui berdasarkan hasil penilaian dari ahli materi dan ahli media. Perolehan skor dari ahli media menghasilkan persentase sebesar 94\% . Sedangkan perolehan skor dari ahli materi menghasilkan persentase sebesar $97 \%$. Berdasarkan penilaian tersebut, media ular tangga berbantuan flashcard sangat layak untuk diujicobakan. Berdasarkan uji-t menunjukkan adanya perbedaan rata-rata dengan hasil $t_{\text {hitung }}$ $>t_{\text {tabel }}$ yaitu $10,23>2,011$. Sedangkan berdasarkan uji n-gain menunjukkan adanya peningkatan rata-rata sebesar 0,562 dengan selisih rata-rata 25,4 dan tergolong dalam kriteria sedang. Sehingga media ular tangga berbantuan flashcard efektif dalam meningkatkan hasil belajar keterampilan menulis deskripsi pada muatan pelajaran bahasa Indonesia kelas IV SDN Mangkang Kulon 02.

\section{UCAPAN TERIMAKASIH}

Peneliti mengucapkan terimakasih kepada Allah Swt. dan kepada kedua orang tua yang selalu memberikan doa, motivasi, dukungan moral dan material kepada peneliti, Drs. Sukardi, S.Pd., M.Pd. selaku dosen pembimbing skripsi, Fitria Dwi Prasetyaningtyas, S.Pd., M.Pd., selaku mitra bestari I, dan Drs. Purnomo, M.Pd., M.Pd., selaku mitra bestari II.

\section{DAFTAR PUSTAKA}

Arsyad, A. (2014). Media Pembelajaran. Jakarta: PT. Rajagrafindo Persada.

Chabib, M., Djatmika, E. T., \& Kuswandi, D. (2017). Efektivitas Pengembangan Media Permainan Ular Tangga Sebagai Sarana Belajar Tematik SD. Jurnal Pendidikan: Teori, Penelitian, dan Pengembangan , 910-918.

Dalman, H. (2016). Keterampilan Menulis. Depok: Rajawali Pers.

Herlina. (2017). Flashcard Media: The Media for Developing Students Understanding for English Vacabulary at Elementary School Volume 4 No. 1. IJER: Internasional Journal of Educational Review Vol 4 (1), 116-128.

Hidayat, T., Hidayatullah, A., \& Agustini, R. (2019). Kajian Permainan Edukasi dalam Pembelajaran Bahasa Indonesia. Deiksis: Jurnal Pendidikan Bahasa dan Sastra, 59-68.

Husna, A. (2009). 100+ Permainan Tradisional Indonesia untuk Kreativitas, Ketangkasan, dan Keakraban. Yogyakarta: ANDI.

Indot. (2018). Meningkatkan Kemampuan Membaca dan Menulis Siswa Kelas I dengan Menggunakan Media Flashcard SD Negeri 006 Sungai 
Buluh Kecamatan Singingi Hilir Kabupaten Kuantan Singingi. Jurnal PAJAR Volume 2 (5), 666-673.

Maslakah, N. (2017). Pengaruh Pendidikan Media Flashcard Terhadap Pengetahuan Anak Tentang Pedoman Umum Gizi Seimbang di SD Muhammadiyah $21 \quad$ Baluwarti Surakarta. Jurnal Kesehatan Volume 10 (1), 9-16.

Mentara, H. (2017). Pengembangan Media Ular Tangga Sebagai Media Pembelajaran Penjasorkes Pada Siswa Kelas IV Sekolah Dasar (SD) Model Terpadu Madani. Tadulako Journal Sport Sciences and Physical Education Vol. VII (2), 58-72.

Meriyati. (2019). Snake and Ladder Game Integrated with Asmaul-husna: Development of Learning Media. Journal of Physics, 1-8.

Nisak, R. (2012). Seabrek Games Asyik Edukatif untuk Mengajar PAUD/TK. Jogjakarta: DIVA Pres.

Peraturan Menteri Pendidikan Nasional Nomor 21 Tahun 2016 tentang Standar Isi. (2016).

Pratiwi, D. E., Yulianto, B., \& Suhartono. (2016). Pengembangan Media Flashcard Berbasis Macromedia Flash Pada Pembelajaran Bahasa Indonesia Model Think Talk Write Untuk Meningkatkan Kemampuan Menulis Siswa Kelas IV Sekolah Dasar. Jurnal
Review Pendidikan Dasar: Jurnal Kajian Pendidikan dan Hasil Penelitian Vol. 2 (1), 105-111.

Pratiwi, Y. I. (2017). The Development of 'Snake and Ladder' Learning Media to Enrich Indonesian Vocabulary in Thematic Intruction for Fourth Grade Students. International Journal of Elementary Education Volume 1 (2), 161167.

Sadiman, A. S. (2012). Media Pembelajaran. Depok: PT Rajagrafindo Perkasa.

Susanto, A. (2013). Teori Belajar \& Pembelajaran di Sekolah Dasar. Jakarta: Prenamedia Group.

Suananda, I. K. (2018). Melestarikan Kearifan Budaya Lokal Melalui Permainan Tradisional Ular Tangga. ADI WIDYA: Jurnal Pendidikan Dasar, 7882.

Tarigan, H. G. (2013). MENULIS Sebagai Suatu Keterampilan Berbahasa. Bandung: Angkasa.

Ulwiya, M. N. (2018). Penggunaan Media Flashcard untuk Meningkatkan Keterampilan Menulis Deskripsi Siswa di Sekolah Dasar. Jurnal JPGSD Vol 6 (4), 536-545.

Undang-Undang Republik Indonesia Nomor 20 Tahun 2003 Tentang Sistem Pendidikan Nasional . (2003). 